\title{
Note of clarification of data in the paper titled X-ray repair cross-complementing group 1 codon 399 polymorphism and lung cancer risk: an updated meta-analysis
}

\author{
Wenlong Zhai ${ }^{1}$ - Ruo Feng ${ }^{2}$ - Haiyu Wang ${ }^{3}$ - Yadong Wang ${ }^{3}$
}

Received: 4 January 2015 / Accepted: 24 March 2015 / Published online: 3 April 2015

(C) International Society of Oncology and BioMarkers (ISOBM) 2015

\begin{abstract}
We read with great interest the paper titled "X-ray repair cross-complementing group 1 codon 399 polymorphism and lung cancer risk: an updated meta-analysis" published by Wang et al in Tumor Biology, 2014, 35:411-418. Their results suggest that codon 399 polymorphism of XRCC1 gene might contribute to individual's susceptibility to lung cancer in Asian population and especially in nonsmoking Chinese women. The result is encouraging. Nevertheless, several key issues are worth noticing.
\end{abstract}

\section{Keywords XRCC1 · Polymorphism · Lung cancer · Risk}

The X-ray repair cross-complementing group 1 (XRCC1) gene is a major DNA repair gene involved in base excision repair (BER) and single-strand break (SSB) repair. XRCC1 interacts strongly with poly[ADP-ribose] polymerase 1 (PARP1), which recognizes SSBs, and LIGIII that seals SSBs and BER intermediates [1]. Several single nucleotide polymorphisms (SNPs) have been identified in the XRCC1 gene [2], and the potential associations with lung cancer risk have been proposed [3-6]. Among them, a polymorphism of rs25487 (Arg399Gln, G>A) is one the most extensively

Wenlong Zhai and Ruo Feng contributed equally to this work.

Yadong Wang

wangyd76@yahoo.com; wangyd76@163.com

1 Department of General Surgery, First Affiliated Hospital of Zhengzhou University, Zhengzhou 450052, China

2 Department of Histology and Embryology, School of Basic Medicine, Zhengzhou University, Zhengzhou 450001, China

3 Department of Toxicology, Henan Center for Disease Control and Prevention, Zhengzhou 450016, China studied SNPs, which leads to amino acid substitutions (exon 10). This mutation could alter XRCC1 function, diminish repair kinetics, and influence susceptibility to cancers. To date, a considerable number of studies have investigated the association between XRCC1 Arg399Gln polymorphism and lung cancer risk [7-54]. However, the results remained conflicting rather than conclusive.

Recently, we have read with great interest the paper titled "X-ray repair cross-complementing group 1 codon 399 polymorphism and lung cancer risk: an updated meta-analysis" published online in Tumor Biology, 2014, 35:411-418 [3]. The authors performed a meta-analysis of 46 studies on the association between XRCC1 codon 399 polymorphism and lung cancer risk published before June 2013. In general population, the authors found that the M (Gln) allele and MM (Gln/Gln) genotype were associated with an increased risk of lung cancer compared with C (Arg) allele and CC (Arg/ Arg) genotype, and the odds ratios (ORs) were 1.06 [95\% confidence interval $(95 \% \mathrm{CI}) 1.01-1.12]$ and $1.19(95 \% \mathrm{CI}$ 1.05-1.34), respectively. When it was stratified according to Asian population, the association between XRCC1 codon 399 polymorphism and lung cancer risk was further strengthened. It is an extremely interesting study.

However, after carefully examining the data provided by Wang et al. (Table 1 in the original text) [3], we found that there are several overlapping data that were not properly excluded from Wang et al.'s study [3]. Firstly, the data from Zhang et al.'s study [55] overlapped with the data reported by Hao et al. [17]. Secondly, the data from Liu et al.'s study [56] overlapped with Zhou et al.'s data [47]. Thirdly, the data reported by Yin et al. in 2009 [57] overlapped with the data reported by Yin et al. in 2007 [44]. Fourthly, Hung et al.'s paper published in 2008 [58] was a pooled analysis study, which included the data from Hung et al.'s paper published in 2005 [20], Zhou et al.'s paper published in 2003 [47], 
Table 1 Characteristics of selected studies in this meta-analysis

\begin{tabular}{|c|c|c|c|c|c|c|c|}
\hline Author & Year & Ethnicity & Country & Source of control & Cases & Controls & $P$ value of $\mathrm{HWE}$ \\
\hline Chan [7] & 2005 & Asians & China & Hospital & 75 & 162 & 0.879127 \\
\hline Chang [8] & 2009 & Africans and Latinos & USA & Population & 368 & 578 & 0.592618 \\
\hline Chen [9] & 2002 & Asians & China & Population & 103 & 99 & 0.853812 \\
\hline Cote $[10]$ & 2009 & Africans and Caucasians & USA & Population & 502 & 527 & 0.893601 \\
\hline David-Beabes [11] & 2001 & Africans and Caucasians & USA & Population & 334 & 704 & 0.465443 \\
\hline De-Ruyck [12] & 2007 & Caucasians & Belgium & Hospital & 109 & 109 & 0.916778 \\
\hline Divine [13] & 2001 & Caucasians & USA & Hospital & 172 & 143 & 0.579995 \\
\hline Du [14] & 2012 & Asians & China & Hospital & 100 & 100 & 0.000006 \\
\hline $\mathrm{Du}[15]$ & 2014 & Asians & China & Hospital & 120 & 120 & 0.000000 \\
\hline Guo [16] & 2013 & Asians & China & Hospital & 684 & 602 & 0.005453 \\
\hline Hao [17] & 2006 & Asians & China & Population & 1024 & 1118 & 0.101696 \\
\hline Harms [18] & 2004 & Caucasians & Germany & Population & 110 & 119 & 0.256632 \\
\hline $\mathrm{Hu}$ [19] & 2005 & Asians & China & Population & 710 & 710 & 0.679058 \\
\hline Hung [20] & 2005 & Caucasians & France & Hospital & 2049 & 2015 & 0.105562 \\
\hline Improta [21] & 2008 & Caucasians & Italy & Population & 94 & 121 & 0.049457 \\
\hline Ito [22] & 2004 & Asians & Japan & Hospital & 178 & 448 & 0.749648 \\
\hline Janik [23] & 2011 & Caucasians & Poland & Hospital & 88 & 79 & 0.055572 \\
\hline $\operatorname{Kim}[24]$ & 2010 & Asians & Korea & Population & 139 & 217 & 0.318155 \\
\hline Kiyohara [25] & 2012 & Asians & Japan & Hospital & 462 & 379 & 0.858615 \\
\hline Letkova [49] & 2013 & Caucasians & Slovak & Unknown & 382 & 379 & 0.097863 \\
\hline $\operatorname{Li}[26]$ & 2008 & Asians & China & Hospital & 350 & 350 & 0.239615 \\
\hline Li [27] & 2011 & Asians & China & Hospital & 455 & 443 & 0.052370 \\
\hline Lopez-Cima [28] & 2007 & Caucasians & Spain & Hospital & 516 & 533 & 0.153908 \\
\hline Matullo [29] & 2006 & Caucasians & Italy & Population & 116 & 1094 & 0.632227 \\
\hline Misra [30] & 2003 & Caucasians & Finland & Population & 315 & 313 & 0.835918 \\
\hline Natukula [50] & 2013 & Asians & India & Unknown & 100 & 101 & 0.266487 \\
\hline Osawa [31] & 2010 & Asians & Japan & Hospital & 104 & 120 & Not estimable \\
\hline Ouyang [32] & 2013 & Asians & China & Population & 82 & 201 & 0.148702 \\
\hline Pachouri [33] & 2007 & Asians & India & Population & 103 & 122 & 0.055915 \\
\hline Park [34] & 2002 & Asians & Korea & Population & 192 & 135 & 0.739912 \\
\hline Popanda [35] & 2004 & Caucasians & Germany & Hospital & 463 & 460 & 0.845748 \\
\hline Qian [36] & 2011 & Asians & China & Population & 581 & 603 & 0.411222 \\
\hline Ratnasinghe [37] & 2001 & Asians & China & Population & 107 & 208 & 0.572907 \\
\hline Saikia [51] & 2014 & Asians & India & Population & 272 & 544 & 0.354912 \\
\hline Schneider [38] & 2005 & Caucasians & Germany & Hospital & 446 & 622 & 0.778779 \\
\hline Shen [39] & 2005 & Asians & China & Population & 116 & 109 & 0.053219 \\
\hline Song [40] & 2004 & Asians & China & Hospital & 104 & 104 & 0.466350 \\
\hline $\mathrm{Su}[41]$ & 2008 & Asians & China & Hospital & 162 & 244 & 0.848338 \\
\hline Uppal [52] & 2014 & Asians & India & Unknown & 100 & 100 & 0.001582 \\
\hline Vogel [42] & 2004 & Caucasians & Denmark & Population & 256 & 269 & 0.522834 \\
\hline Wang [43] & 2012 & Asians & China & Hospital & 209 & 256 & 0.302192 \\
\hline Yin [44] & 2007 & Asians & China & Hospital & 205 & 193 & 0.198358 \\
\hline Yoo [53] & 2015 & Asians & Korea & Hospital & 599 & 580 & 0.217986 \\
\hline $\mathrm{Yu}[45]$ & 2006 & Asians & China & Hospital & 104 & 121 & 0.288300 \\
\hline Zhang [46] & 2005 & Asians & China & Hospital & 149 & 157 & 0.853973 \\
\hline Zhou [47] & 2003 & Caucasians & USA & Population & 1091 & 1240 & 0.661362 \\
\hline Zhu [54] & 2014 & Asians & China & Unknown & 320 & 346 & 0.941896 \\
\hline Zienolddiny [48] & 2006 & Caucasians & Norway & Population & 331 & 391 & 0.784938 \\
\hline
\end{tabular}

HWE Hardy-Weinberg equilibrium 


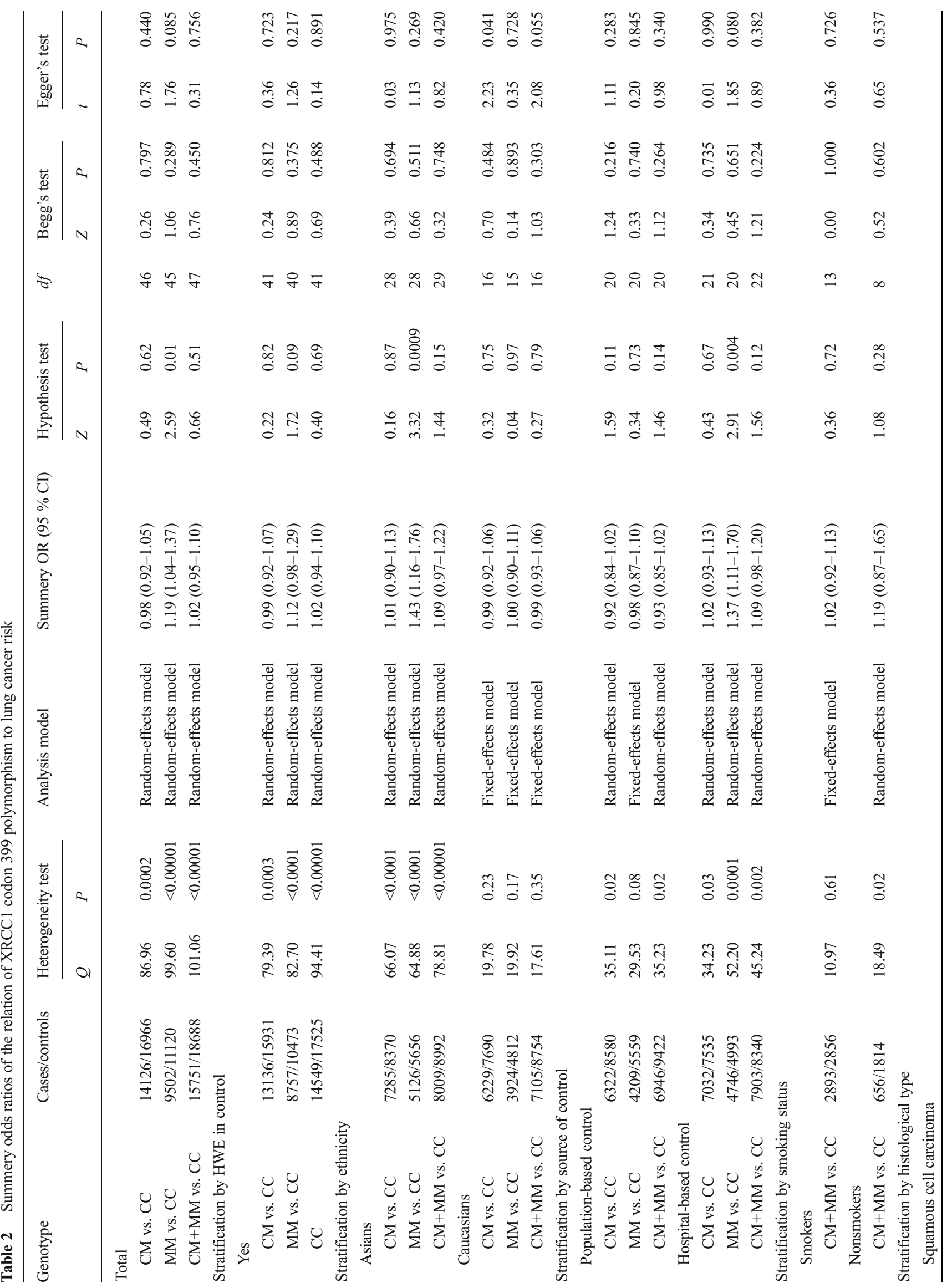


Popanda et al.'s paper published in 2004 [35], and Shen et al.'s paper published in 2005 [39]. Fifthly, the data from two papers reported by Li et al. in 2005 [59, 60] overlapped with Li et al.'s paper published in 2008 [26]. Sixthly, the data from Li et al.'s published in 2005 [61] overlapped with the data reported by Su et al. [41]. As a consequence, 5986 cases and 6495 controls were calculated two times in Wang et al.'s paper [3]. In addition, two eligible papers [7, 23] published before 2013 was not included in Wang et al.'s paper [3]. Therefore, it is required to verify the conclusions by Wang et al. [3]. In order to clarify the association between XRCC1 Arg399Gln polymorphism and lung cancer risk, a meta-analysis including the updated data was reconducted, which may provide comprehensive evidence for this association. We also presented the stratified results by mainly confounding factors such as source of control, ethnicity, smoking status, histological subtypes, and Hardy-Weinberg equilibrium (HWE) in control besides giving overall estimates.

A comprehensive search was performed through the database of Medline/PubMed, Science Direct, Elsevier, China National Knowledge Infrastructure (CNKI), and Wanfang Medical Online with a combination of the following terms: "lung cancer," "lung neoplasm" or "lung carcinoma" and "XRCC1" or "rs25487" and "polymorphism" or "variant." Last search was updated on March 20, 2015. The references cited in the publications and review articles were also manually searched.

Data inclusion criteria were as follows: (a) the papers reporting lung cancer risk and XRCC1 codon 399 polymorphism; (b) case-control studies or cohort studies; and (c) sufficient data to estimate the OR and $95 \%$ CI. For overlapping or repeated studies, the results including more information were included. Accordingly, papers lacking essential information were excluded; review papers were also excluded. In total, 69 published papers were identified with the association between XRCC1 Arg399Gln polymorphism and lung cancer risk. We reviewed all papers in the light of the criteria defined above and excluded 12 reviews and 9 overlapping articles. Therefore, 48 studies were determined to enter our study.

The Cochrane $Q$ statistics test was used to assess the heterogeneity among studies. A fixed-effects model or a random-effects model was applied to estimate the combined effects according to the results of heterogeneity test [62]. A fixed-effects model is used while the effects are assumed to be homogenous; otherwise, a randomeffects model is used. The funnel plot was drawn to evaluate publication bias visually. In addition, Begg's test and Egger's test were used to assess the publication bias $[63,64]$. The $\chi^{2}$ test was used to check whether the genotype frequencies of the controls were in agreement with HWE. 
All of the statistical analyses were conducted by using Review Manager (version 4.2.10, the Cochrane Collaboration) and STATA10.0 software package (Stata Corporation, College Station, TX). Statistical significance was determined as a two-sided $P$ value less than 0.05 for any test or model.

Table 1 lists the characteristics of included studies. Table 2 lists the summary effects of the association
Fig. 1 Forest plots for the association between XRCC1 codon 399 MM genotype variant and lung cancer risk
Odds Ratio

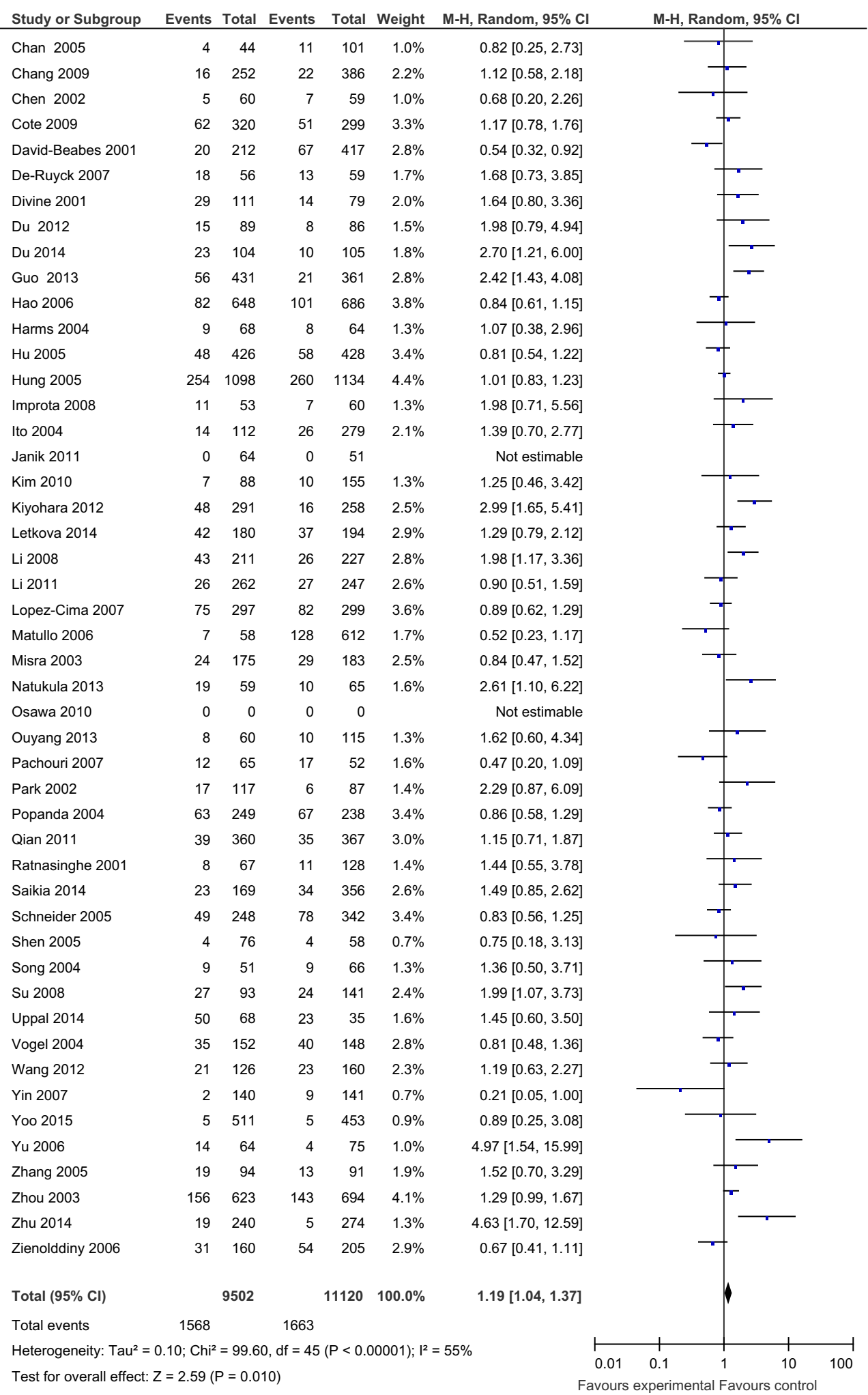


between XRCC1 codon 399 polymorphism and lung cancer risk on the basis of 48 published studies including 15,751 cases and 18,688 controls. Overall, we observed a significant association between XRCC1 codon
399 MM genotype variant and lung cancer risk, and the summary OR was 1.19 (95\%CI 1.04-1.37) (Fig. 1); we did not observe any association between XRCC1 codon $399 \mathrm{CM}$ and $\mathrm{CM}+\mathrm{MM}$ genotype variants and lung
Fig. 2 Forest plots for the association between XRCC1 codon 399 CM genotype variant and lung cancer risk
Case Control

Odds Ratio

Odds Ratio

Study or Subgroup Events Total Events Total Weight M-H, Random, 95\% Cl $\quad$ M-H, Random, $95 \% \mathrm{C}$

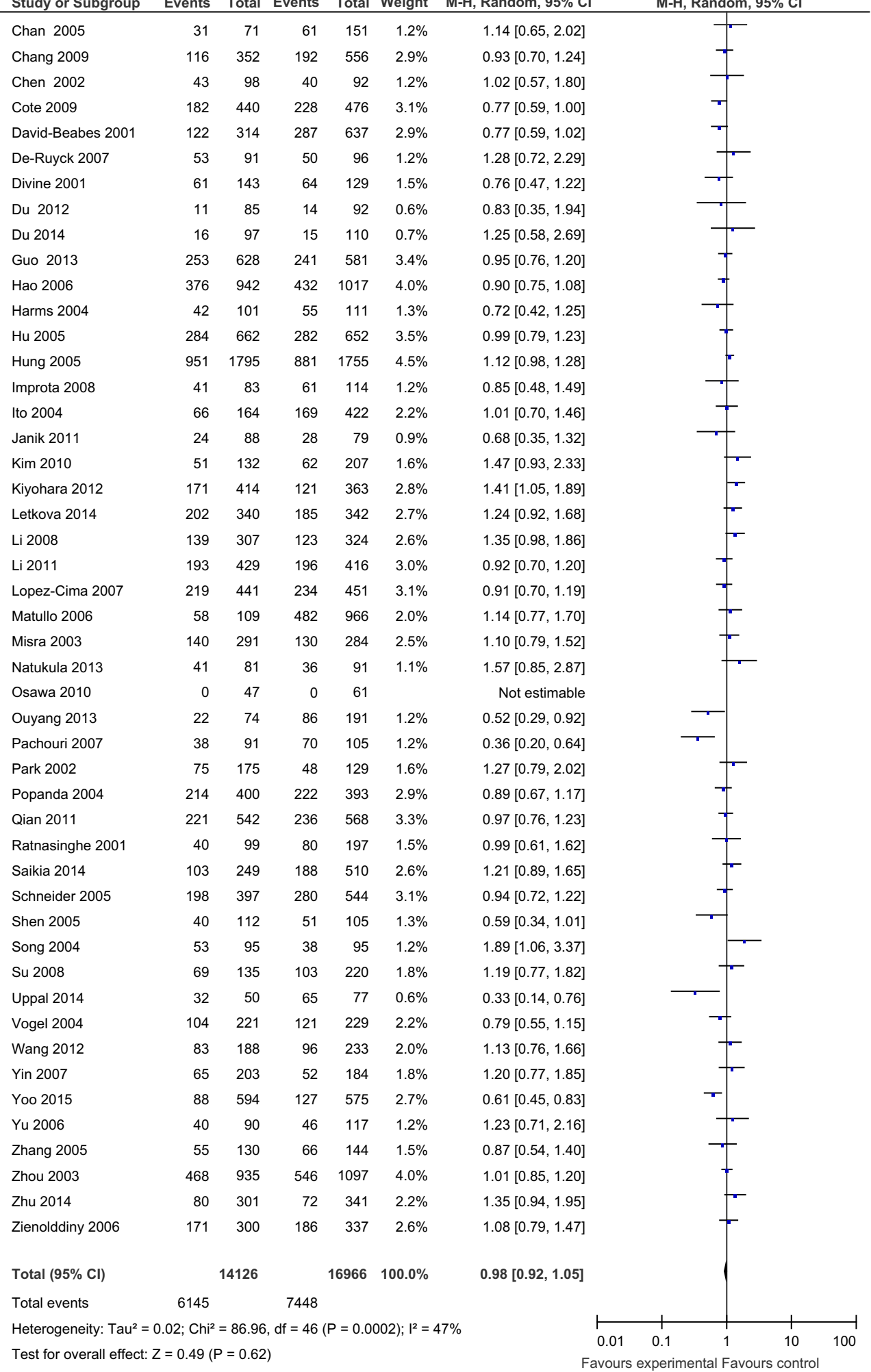


cancer risk, and the summary ORs were $0.98(95 \% \mathrm{CI}$ 0.92-1.05) for CM vs. CC (Fig. 2) and 1.02 (95\% CI 0.95-1.10) for $\mathrm{CM}+\mathrm{MM}$ vs. CC (Fig. 3), respectively. Our results are consistent with Wang et al.'s study [3].
They also found that the MM genotype was associated with increased risk of lung cancer compared with $\mathrm{CC}$ genotype in total population. Limiting the analysis to studies of control in agreement with HWE, we did not
Fig. 3 Forest plots for the association between XRCC1 codon $399 \mathrm{CM}+\mathrm{MM}$ genotype variant and lung cancer risk

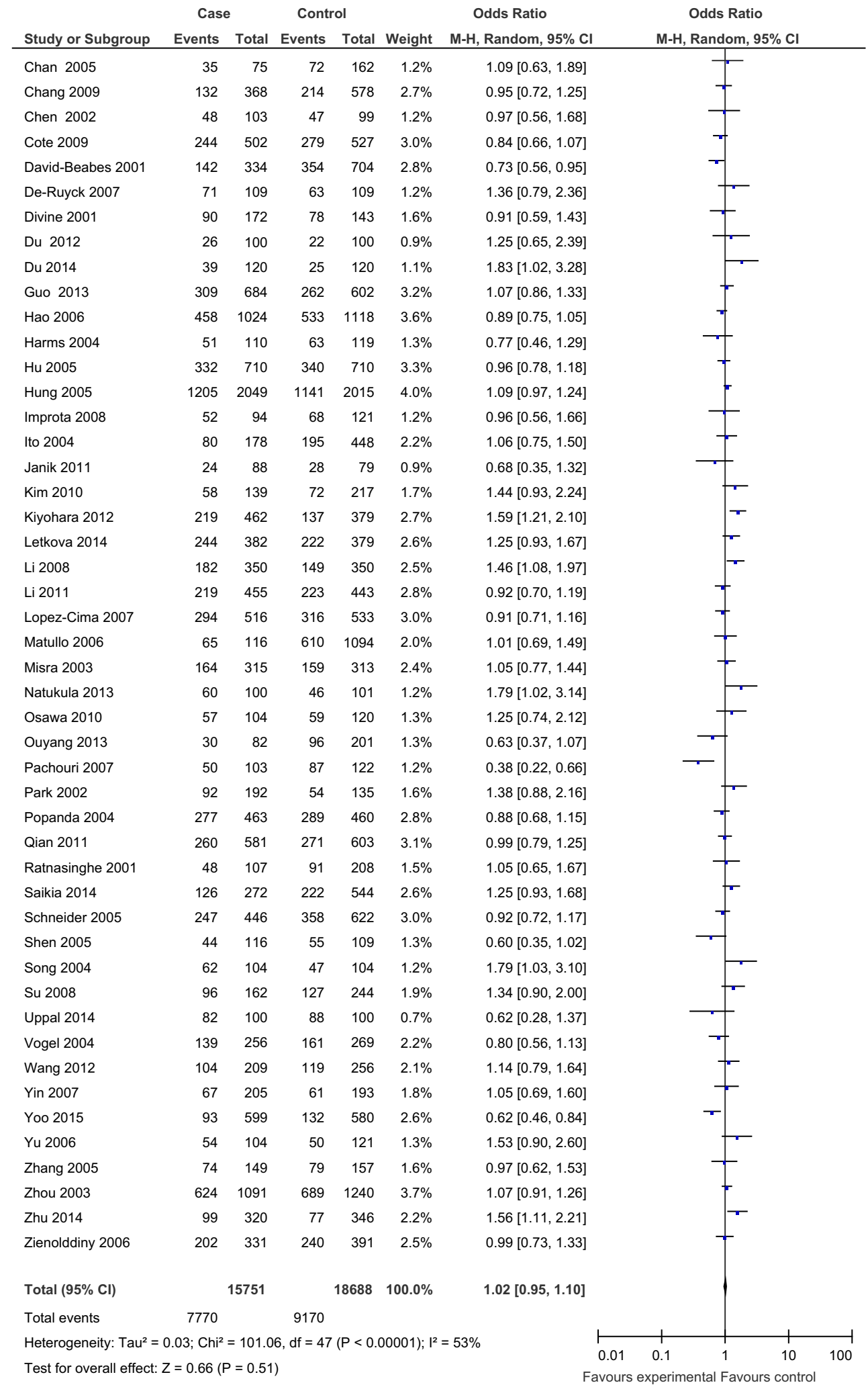


Fig. 4 Funnel plots for the association between XRCC1 codon 399 MM genotype variant and lung cancer risk

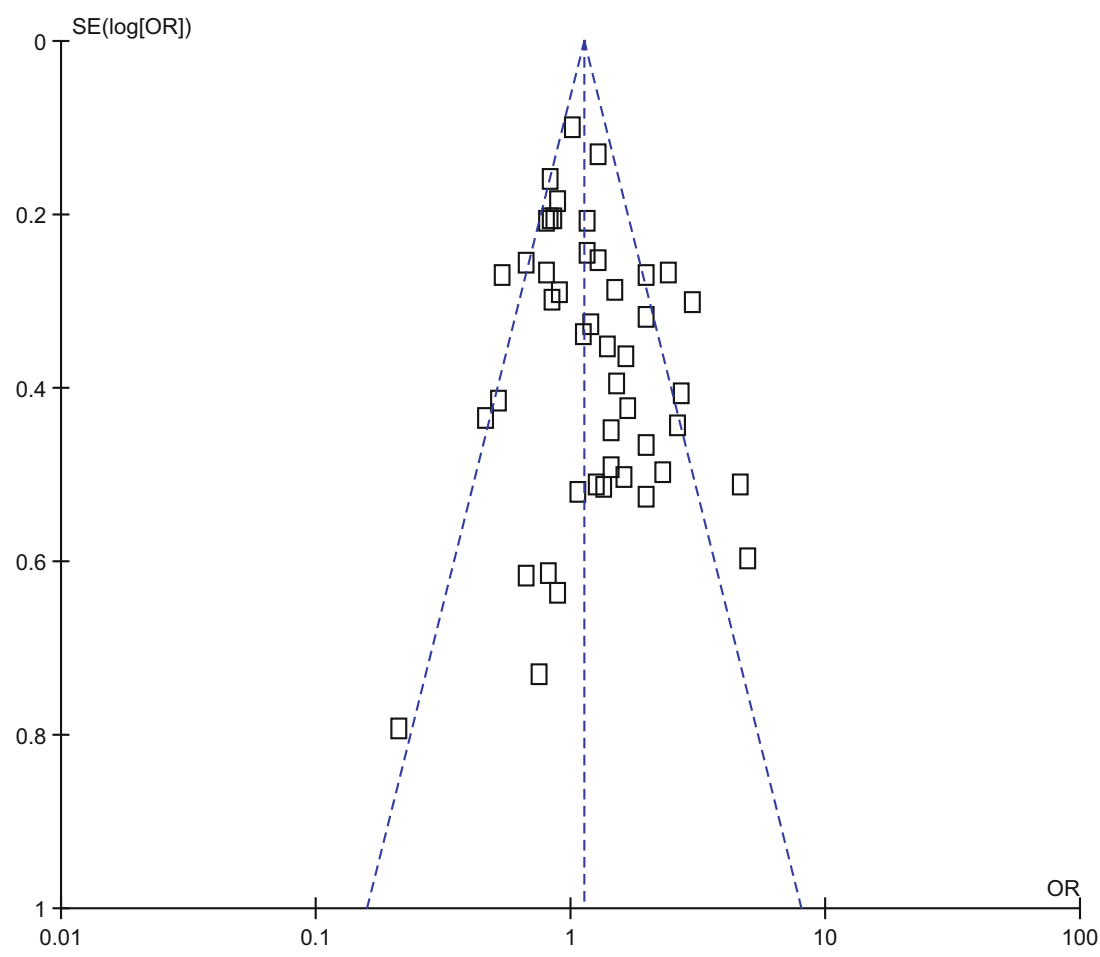

observe the association between XRCC1 codon 399 polymorphism and lung cancer risk, the summary ORs were 0.99 (95\% CI 0.92-1.07) for CM vs. CC, 1.12 (95\% CI 0.98-1.29) for MM vs. CC, and 1.02 (95\% CI 0.94-1.10) for $\mathrm{CM}+\mathrm{MM}$ vs. CC, respectively (Table 2). In subgroup analysis by ethnicity, we observed an increased lung cancer risk among subjects carrying XRCC1 codon 399 MM genotype compared with $\mathrm{CC}$ genotype carriers $(\mathrm{OR}=1.43,95 \%$ CI 1.16 1.76) among Asians, which is consistent with Wang et al.'s results [3]. We did not observe the association of XRCC1 codon 399 polymorphism with lung cancer
Fig. 5 Funnel plots for the association between XRCC1 codon 399 CM genotype variant and lung cancer risk

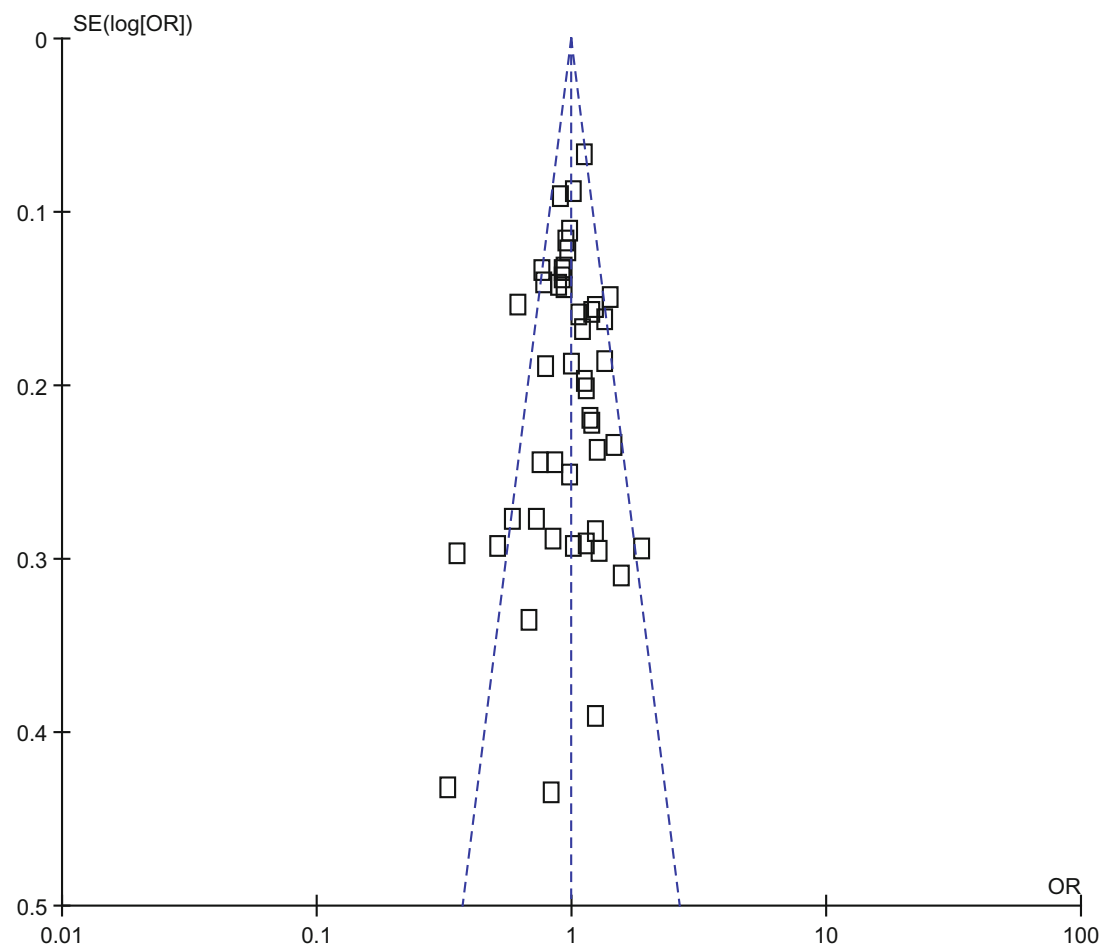


Fig. 6 Funnel plots for the association between XRCC1 codon $399 \mathrm{CM}+\mathrm{MM}$ genotype variant and lung cancer risk

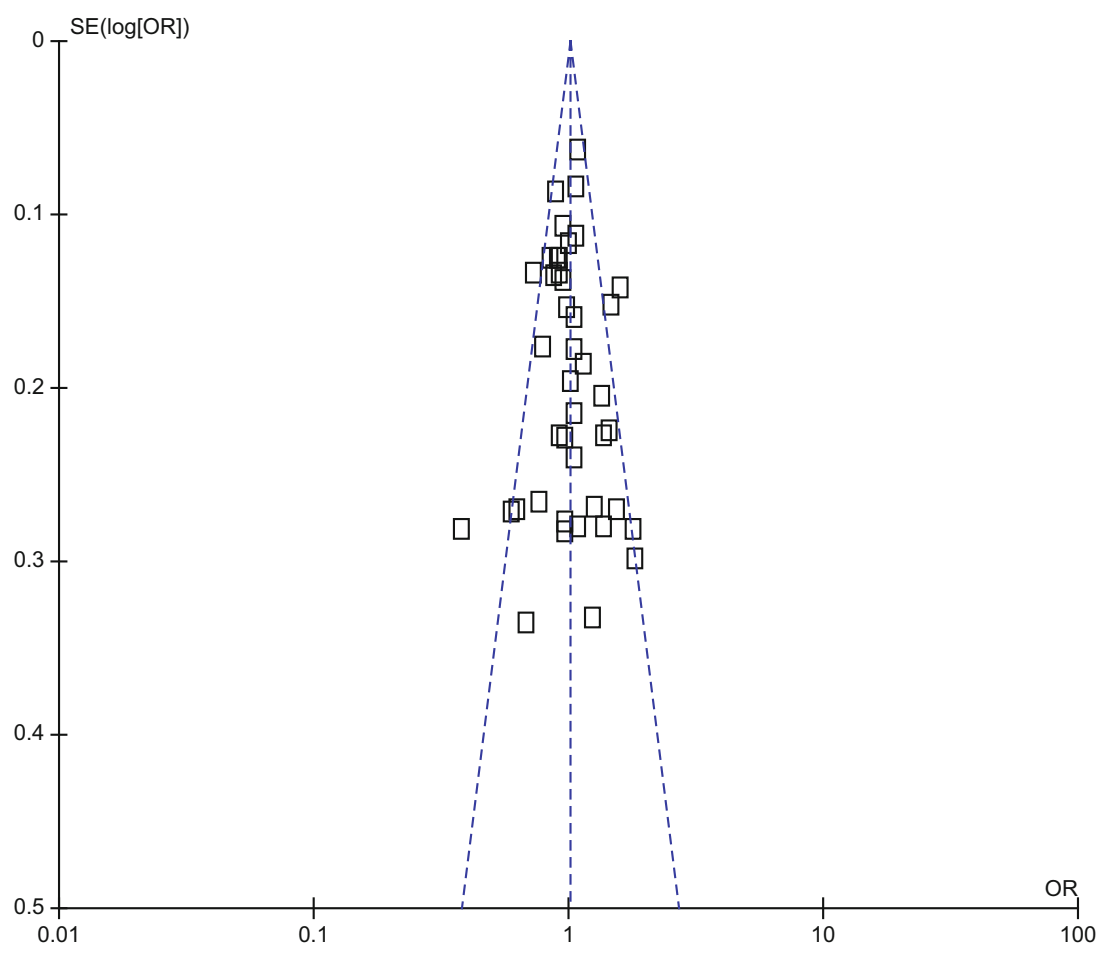

risk among Caucasians (Table 2), which is consistent with Wang et al.'s results [3]. When stratified by source of control, we observed an increased lung cancer risk among subjects carrying MM genotype compared with those carrying CC genotype on the basis of hospitalbased control $(\mathrm{OR}=1.37,95 \% \mathrm{CI} 1.11-1.70)$; we did not observe the association of XRCC1 codon 399 polymorphism with lung cancer risk on the basis of population-based control (Table 2). We did not observe the association between XRCC1 codon 399 polymorphism and lung cancer risk in additional subgroup analyses by smoking status and histological subtypes (Table 2).

The shape of funnel plots did not reveal any evidence of obvious asymmetry (Figs. 4, 5, and 6) among total studies, which suggested that there was not any potential publication bias. Begg's test and Egger's test suggested that there was no obvious publication bias in this study, except for the analysis under the genetic model of CM vs. MM among Caucasians, since the $P$ value was less than 0.05 in Egger's test (Table 2).

In summary, our results suggest that XRCC1 codon 399 MM genotype variant was associated with an increased lung cancer risk, especially among Asians. To reach a definitive conclusion, further well-designed studies with large sample size are needed to verify the association of XRCC1 codon 399 polymorphism and lung cancer risk. We hope that this remark will contribute to a more accurate elaboration and substantiation of the results presented by Wang et al. [3].
Conflicts of interest None

\section{References}

1. Vidal AE, Boiteux S, Hickson ID, Radicella JP. XRCC1 coordinates the initial and late stages of DNA abasic site repair through protein-protein interactions. EMBO J. 2001;20:6530-9.

2. Shen MR, Jones IM, Mohrenweiser H. Nonconservative amino acid substitution variants exist at polymorphic frequency in DNA repair genes in healthy humans. Cancer Res. 1998;58:604-8.

3. Wang JY, Cai Y. X-ray repair cross-complementing group 1 codon 399 polymorphism and lung cancer risk: an updated meta-analysis. Tumour Biol. 2014;35:411-8.

4. Zheng H, Wang Z, Shi X. XRCC1 polymorphisms and lung cancer risk in Chinese populations: a meta-analysis. Lung Cancer. 2009;65:268-73.

5. Guo QX, Yang WH, Zhai JF, Han FC, Wang CY. XRCC1 codon 280 polymorphism and susceptibility to lung cancer: a metaanalysis of the literatures. Tumour Biol. 2013;34:2989-94.

6. Zhang J, Zeng XT, Lei JR, Tang YJ, Yang J. No association between XRCC1 gene Arg194Trp polymorphism and risk of lung cancer: evidence based on an updated cumulative meta-analysis. Tumour Biol. 2014;35:5629-35.

7. Chan EC, Lam SY, Fu KH, Kwong YL. Polymorphisms of the GSTM1, GSTP1, MPO, XRCC1, and NQO1 genes in Chinese patients with non-small cell lung cancers: relationship with aberrant promoter methylation of the CDKN2A and RARB genes. Cancer Genet Cytogenet. 2005;162:10-20.

8. Chang JS, Wrensch MR, Hansen HM, Sison JD, Aldrich MC, Quesenberry Jr CP, et al. Base excision repair genes and risk of lung cancer among San Francisco Bay Area Latinos and AfricanAmericans. Carcinogenesis. 2009;30:78-87. 
9. Chen S, Tang D, Xue K, Xu L, Ma G, Hsu Y, et al. DNA repair gene $\mathrm{XRCC} 1$ and XPD polymorphisms and risk of lung cancer in a Chinese population. Carcinogenesis. 2002;23:1321-5.

10. Cote ML, Yoo W, Wenzlaff AS, Prysak GM, Santer SK, Claeys $\mathrm{GB}$, et al. Tobacco and estrogen metabolic polymorphisms and risk of non-small cell lung cancer in women. Carcinogenesis. 2009;30: 626-35.

11. David-Beabes GL, London SJ. Genetic polymorphism of XRCC1 and lung cancer risk among African-Americans and Caucasians. Lung Cancer. 2001;34:333-9.

12. De Ruyck K, Szaumkessel M, De Rudder I, Dehoorne A, Vral A, Claes K, et al. Polymorphisms in base-excision repair and nucleotide-excision repair genes in relation to lung cancer risk. Mutat Res. 2007;631:101-10.

13. Divine KK, Gilliland FD, Crowell RE, Stidley CA, Bocklage TJ, Cook DL, et al. The XRCC1 399 glutamine allele is a risk factor for adenocarcinoma of the lung. Mutat Res. 2001;461:273-8.

14. Du Y, Chu DJ, Shi JM, Fan W. The relationship between lung cancer and genetic polymorphism of XRCC1. J Clin Intern Med. 2012;29:346-8.

15. Du Y, He Y, Mei Z, Qian L, Shi J, Jie Z. Association between genetic polymorphisms in XPD and XRCC1 genes and risks of non-small cell lung cancer in East Chinese Han population. Clin Respir J. 2014. doi:10.1111/crj.12218.

16. Guo S, Li X, Gao M, Li Y, Song B, Niu W. The relationship between XRCC1 and XRCC3 gene polymorphisms and lung cancer risk in northeastern Chinese. PLoS One. 2013;8:e56213.

17. Hao B, Miao X, Li Y, Zhang X, Sun T, Liang G, et al. A novel $\mathrm{T}-77 \mathrm{C}$ polymorphism in DNA repair gene XRCC1 contributes to diminished promoter activity and increased risk of non-small cell lung cancer. Oncogene. 2006;25:3613-20.

18. Harms C, Salama SA, Sierra-Torres CH, Cajas-Salazar N, Au WW. Polymorphisms in DNA repair genes, chromosome aberrations, and lung cancer. Environ Mol Mutagen. 2004;44:74-82.

19. $\mathrm{Hu} \mathrm{Z,} \mathrm{Ma} \mathrm{H,} \mathrm{Lu} \mathrm{D,} \mathrm{Zhou} \mathrm{J,} \mathrm{Chen} \mathrm{Y,} \mathrm{Xu} \mathrm{L,} \mathrm{et} \mathrm{al.} \mathrm{A} \mathrm{promoter}$ polymorphism $(-77 \mathrm{~T}>\mathrm{C})$ of DNA repair gene $\mathrm{XRCC} 1$ is associated with risk of lung cancer in relation to tobacco smoking. Pharmacogenet Genomics. 2005;15:457-63.

20. Hung RJ, Brennan P, Canzian F, Szeszenia-Dabrowska N, Zaridze $\mathrm{D}$, Lissowska J, et al. Large-scale investigation of base excision repair genetic polymorphisms and lung cancer risk in a multicenter study. J Natl Cancer Inst. 2005;97:567-76.

21. Improta G, Sgambato A, Bianchino G, Zupa A, Grieco V, La Torre $\mathrm{G}$, et al. Polymorphisms of the DNA repair genes XRCC1 and $\mathrm{XRCC} 3$ and risk of lung and colorectal cancer: a case-control study in a Southern Italian population. Anticancer Res. 2008;28:2941-6.

22. Ito H, Matsuo K, Hamajima N, Mitsudomi T, Sugiura T, Saito T, et al. Gene-environment interactions between the smoking habit and polymorphisms in the DNA repair genes, APE1 Asp148Glu and XRCC1 Arg399Gln, in Japanese lung cancer risk. Carcinogenesis. 2004;25:1395-401.

23. Janik J, Swoboda M, Janowska B, Ciesla JM, Gackowski D, Kowalewski J, et al. 8-Oxoguanine incision activity is impaired in lung tissues of NSCLC patients with the polymorphism of OGG1 and XRCC1 genes. Mutat Res. 2011;709-710:21-31.

24. Kim IS, Lee GW, Kim DC, Kim HG, Kim S, Oh SY, et al. Polymorphisms and haplotypes in the XRCC1 gene and the risk of advanced non-small cell lung cancer. J Thorac Oncol. 2010;5: 1912-21.

25. Kiyohara C, Horiuchi T, Takayama K, Nakanishi Y. Genetic polymorphisms involved in carcinogen metabolism and DNA repair and lung cancer risk in a Japanese population. J Thorac Oncol. 2012;7: 954-62.

26. Li M, Yin Z, Guan P, Li X, Cui Z, Zhang J, et al. XRCC1 polymorphisms, cooking oil fume and lung cancer in Chinese women nonsmokers. Lung Cancer. 2008;62:145-51.
27. Li Z, Guan W, Li MX, Zhong ZY, Qian CY, Yang XQ, et al. Genetic polymorphism of DNA base-excision repair genes (APE1, OGG1 and XRCC1) and their correlation with risk of lung cancer in a Chinese population. Arch Med Res. 2011;42:226-34.

28. Lopez-Cima MF, Gonzalez-Arriaga P, Garcia-Castro L, Pascual T, Marron MG, Puente XS, et al. Polymorphisms in XPC, XPD, $\mathrm{XRCC} 1$, and XRCC3 DNA repair genes and lung cancer risk in a population of northern Spain. BMC Cancer. 2007;7:162.

29. Matullo G, Dunning AM, Guarrera S, Baynes C, Polidoro S, Garte $\mathrm{S}$, et al. DNA repair polymorphisms and cancer risk in non-smokers in a cohort study. Carcinogenesis. 2006;27:997-1007.

30. Misra RR, Ratnasinghe D, Tangrea JA, Virtamo J, Andersen MR, Barrett $\mathrm{M}$, et al. Polymorphisms in the DNA repair genes XPD, $\mathrm{XRCC} 1, \mathrm{XRCC} 3$, and $\mathrm{APE} / \mathrm{ref}-1$, and the risk of lung cancer among male smokers in Finland. Cancer Lett. 2003;191:171-8.

31. Osawa K, Miyaishi A, Uchino K, Osawa Y, Inoue N, Nakarai C, et al. APEX1 Asp148Glu gene polymorphism is a risk factor for lung cancer in relation to smoking in Japanese. Asian Pac J Cancer Prev. 2010;11:1181-6.

32. Ouyang FD, Yang FL, Chen HC, Khan MA, Huang FM, Wan XX, et al. Polymorphisms of DNA repair genes XPD, XRCC1, and OGG1, and lung adenocarcinoma susceptibility in Chinese population. Tumour Biol. 2013;34:2843-8.

33. Pachouri SS, Sobti RC, Kaur P, Singh J. Contrasting impact of DNA repair gene XRCC1 polymorphisms Arg399Gln and Arg194Trp on the risk of lung cancer in the north-Indian population. DNA Cell Biol. 2007;26:186-91.

34. Park JY, Lee SY, Jeon HS, Bae NC, Chae SC, Joo S, et al. Polymorphism of the DNA repair gene XRCC1 and risk of primary lung cancer. Cancer Epidemiol Biomarkers Prev. 2002;11:23-7.

35. Popanda O, Schattenberg T, Phong CT, Butkiewicz D, Risch A, Edler L, et al. Specific combinations of DNA repair gene variants and increased risk for non-small cell lung cancer. Carcinogenesis. 2004;25:2433-41.

36. Qian B, Zhang H, Zhang L, Zhou X, Yu H, Chen K. Association of genetic polymorphisms in DNA repair pathway genes with nonsmall cell lung cancer risk. Lung Cancer. 2011;73:138-46.

37. Ratnasinghe D, Yao SX, Tangrea JA, Qiao YL, Andersen MR, Barrett MJ, et al. Polymorphisms of the DNA repair gene XRCC1 and lung cancer risk. Cancer Epidemiol Biomarkers Prev. 2001;10: 119-23.

38. Schneider J, Classen V, Bernges U, Philipp M. XRCC1 polymorphism and lung cancer risk in relation to tobacco smoking. Int J Mol Med. 2005;16:709-16.

39. Shen M, Berndt SI, Rothman N, Mumford JL, He X, Yeager M, et al. Polymorphisms in the DNA base excision repair genes APEX1 and XRCC1 and lung cancer risk in Xuan Wei. China Anticancer Res. 2005;25:537-42.

40. Song Y, Yin L, Pu Y, Liang G, Cui H. Relationship between polymorphisms of DNA repair gene XRCC1 and susceptibility to lung cancer in Nanjing population. J Labour Med. 2004;21:18-21.

41. Su J, Niu R, Liu L, Han X, Shi J, Li J, et al. Regression analysis between polymorphisms of DNA repair gene XRCC1 and susceptibility to lung cancer of nonsmoking women. J Zhengzhou Univ(Medical Sciences). 2008;43:234-8.

42. Vogel U, Nexo BA, Wallin H, Overvad K, Tjonneland A, Raaschou-Nielsen O. No association between base excision repair gene polymorphisms and risk of lung cancer. Biochem Genet. 2004;42:453-60.

43. Wang $\mathrm{N}, \mathrm{Wu} \mathrm{Y}$, Zhou X. Association between genetic polymorphism of metabolizing enzymes and DNA repairing enzymes and the susceptibility of lung cancer in Henan population. Wei Sheng Yan Jiu. 2012;41:251-6.

44. Yin J, Vogel U, Ma Y, Qi R, Sun Z, Wang H. The DNA repair gene $\mathrm{XRCC} 1$ and genetic susceptibility of lung cancer in a northeastern Chinese population. Lung Cancer. 2007;56:153-60. 
45. Yu H, Zeng X, Chou X, Xu S, Shi L, Zhang X, et al. Polymorphism in the DNA repair gene XRCC1 and susceptibility to human lung cancer. J Guangxi Med Univ. 2006;23:355-8.

46. Zhang W, Wu Y, Wu Y. Study on polymorphism of XRCC1 and susceptibility to lung cancer. China Publ Health. 2005;5:561-3.

47. Zhou W, Liu G, Miller DP, Thurston SW, Xu LL, Wain JC, et al. Polymorphisms in the DNA repair genes XRCC1 and ERCC2, smoking, and lung cancer risk. Cancer Epidemiol Biomarkers Prev. 2003;12:359-65.

48. Zienolddiny S, Campa D, Lind H, Ryberg D, Skaug V, Stangeland $\mathrm{L}$, et al. Polymorphisms of DNA repair genes and risk of non-small cell lung cancer. Carcinogenesis. 2006;27:560-7.

49. Letkova L, Matakova T, Musak L, Sarlinova M, Krutakova M, Slovakova $\mathrm{P}$, et al. DNA repair genes polymorphism and lung cancer risk with the emphasis to sex differences. Mol Biol Rep. 2013;40:5261-73.

50. Natukula K, Jamil K, Pingali U, Attili V, Madireddy U. The codon $399 \mathrm{Arg} / \mathrm{Gln}$ XRCC1 polymorphism is associated with lung cancer in Indians. Asian Pac J Cancer Prev. 2013;14:5275-9.

51. Saikia BJ, Phukan RK, Sharma SK, Sekhon GS, Mahanta J. Interaction of XRCC1 and XPD gene polymorphisms with lifestyle and environmental factors regarding susceptibility to lung cancer in a high incidence population in North East India. Asian Pac J Cancer Prev. 2014;15:1993-9.

52. Uppal V, Mehndiratta M, Mohapatra D, Grover RK, Puri D. XRCC-1 Gene Polymorphism (Arg399Gln) and Susceptibility to Development of Lung Cancer in Cohort of North Indian Population: a Pilot Study. J Clin Diagn Res. 2014;8:CC17-20.

53. Yoo SS, Jin C, Jung DK, Choi YY, Choi JE, Lee WK, et al. Putative functional variants of XRCC1 identified by RegulomeDB were not associated with lung cancer risk in a Korean population. Cancer Genet. 2015;208:19-24.
54. Zhu DQ, Zou Q, Hu CH, Su JL, Zhou GH, Liu P. XRCC1 genetic polymorphism acts a potential biomarker for lung cancer. Tumour Biol. 2014. doi:10.1007/s13277-014-3014-6.

55. Zhang X, Miao X, Liang G, Hao B, Wang Y, Tan W, et al. Polymorphisms in DNA base excision repair genes ADPRT and XRCC1 and risk of lung cancer. Cancer Res. 2005;65:722-6.

56. Liu G, Zhou W, Park S, Wang LI, Miller DP, Wain JC, et al. The SOD2 Val/Val genotype enhances the risk of nonsmall cell lung carcinoma by $\mathrm{p} 53$ and XRCC1 polymorphisms. Cancer. 2004;101:2802-8.

57. Yin J, Vogel U, Ma Y, Qi R, Wang H. Association of DNA repair gene XRCC1 and lung cancer susceptibility among nonsmoking Chinese women. Cancer Genet Cytogenet. 2009;188:26-31.

58. Hung RJ, Christiani DC, Risch A, Popanda O, Haugen A, Zienolddiny $\mathrm{S}$, et al. International Lung Cancer Consortium: pooled analysis of sequence variants in DNA repair and cell cycle pathways. Cancer Epidemiol Biomarkers Prev. 2008;17:3081-9.

59. Li M, Cui Z, He Q, Zhou B. Association of genetic polymorphism in the DNA repair gene XRCC1 with susceptibility to lung cancer in non-smoking women. Chin J Oncol. 2005;27:713-6.

60. Li M, Yin Z, Cui Z, He Q, Zhou B. Association of genetic polymorphism in DNA repair gene XRCC1 with risk of lung adenocarcinoma in nonsmoking women. Chin J Lung Cancer. 2005;8:431-4.

61. Li J, Mu L, Wei G, Chen C, Zhang Z, Yu S, et al. Relationship between polymorphisms of DNA repair gene XRCC1 and susceptibility to lung cancer. China Oncol. 2005;15:335-8.

62. DerSimonian R, Laird N. Meta-analysis in clinical trials. Control Clin Trials. 1986;7:177-88.

63. Begg CB, Mazumdar M. Operating characteristics of a rank correlation test for publication bias. Biometrics. 1994;50:1088-101.

64. Egger M, Davey Smith G, Schneider M, Minder C. Bias in metaanalysis detected by a simple, graphical test. BMJ. 1997;315:62934. 